\section{Incorporating Structure and Stochasticity in Muscadine Grape Enterprise Budget and Investment Analysis}

\author{
Sebastain N. Awondo ${ }^{1,4}$, Esendugue Greg Fonsah², \\ and Dennis J. Gray ${ }^{3}$
}

ADDITIONAL INDEX WORDs. stochastic budget, structural dependence, simulations, farm enterprise

Summary. We developed and investigated a stochastic farm enterprise budget framework that properly accounts for uncertainty in estimates used for investment decisions and structural dependency between yields and prices, which is generally absent in traditional (nonstochastic) budgets. In the first stage, we developed a traditional enterprise budget based on theoretical and accounting methods recommended by the American Agricultural Economics Association (AAEA) Task Force on Commodity Costs and Returns. In the second stage, we developed a probabilistic framework based on estimates derived from the traditional approach, and extended the approach to a stochastic framework through Monte Carlo simulations under specific price elasticity of demand. We applied the framework to estimate the costs, revenues, and conducted investment analysis of producing muscadine grapes (Vitis rotundifolia) in Georgia using a single-trellis system. Finally, we compared results derived from both approaches and revealed muscadine grape production and marketing to be an economically sound investment under multiple scenarios. Overall, the confidence placed on traditional budget estimates and investment outcomes was found to be overestimated at least 3 -fold. This suggests that the true uncertainty in the returns and profitability of the business is grossly underestimated, erroneously painting a more promising outlook of investing in muscadine grape production.

$M$ uscadine grape is a species native to the southeastern United States and is well adapted to the warm and humid conditions in this region. Unlike widely consumed "bunch" grapes (primarily Vitis vinifera), muscadine grapes form smaller clusters, unbranched tendrils, and berries with thick skins and a unique fruity aroma, that often abscise from the cluster when ripe (Conner, 2013).

This work was funded by USDA/NIFA Specialty
Crops Research Initiative grant no. 2011-51181-30
entitled "Disease-Resistant Seedless Muscadine Grape
Cultivars Utilizing Eco- and Consumer-Friendly Cis-
genic Modification Technologies" for which we are
indebted. We also express our gratitude to Jacob
Paulk for his insightful contributions that made this
publication possible.

${ }^{1}$ Alabama Center for Insurance Information and Research, Culverhouse College of Commerce, University of Alabama, $201 \mathrm{H}$ Bidgood Hall, P.O. Box 870397, Tuscaloosa, AL 35487

${ }^{2}$ Department of Agricultural \& Applied Economics, University of Georgia, 2360 Rainwater Road, Tifton, GA 31793

${ }^{3}$ Mid-Florida Research and Education Center, Institute of Food and Agricultural Sciences, University of Florida, 2725 Binion Road, Apopka, FL 32703

${ }^{4}$ Corresponding author. E-mail: snawondo@culverhouse. ua.edu.

doi: 10.21273/HORTTECH03466-16
Over the recent decades, advances in plant breeding has ushered in over 100 improved muscadine grape cultivars which include diseaseresistant, high-yielding, seedless, selffertile, and high-juice-quality cultivars that can be used for a range of end products. More recently, some researchers have started deploying "precision breeding" techniques in response to changing consumer preferences for bioengineered food. According to Gray et al. (2014, 2015), recision breeding is a newly enabled approach to plant genetic improvement that transfers only specific desirable traits among sexually compatible relatives via the mitotic cell division pathway to avoid the significant genetic disruption imposed on conventional breeding by meiosis (sexual reproduction). This technology also allows for the development of new cultivars with different attributes (e.g., skin friability, skin thickness, and flesh firmness) with potential to serve the growing and increasingly diverse end-use market segments for muscadine grapes. In addition, the availability of a fairly large cultivar pool makes it possible to find the most suitable location-specific cultivars that will allow growers to maximize production and profits.

Muscadine grapes occupy a niche market where they are marketed as fresh fruit and also processed for jams, juice, and wine. Increasing numbers of studies show that muscadine grapes contain high levels of resveratrol (Ector et al., 1996; Signorelli and Ghidoni, 2005) and other antioxidants that help prevent cardiovascular diseases, fight cancer-causing agents, and enhance the production of estrogen, a female sex hormone (Gu et al., 2006; Olas and Wachowicz, 2005; Signorelli and Ghidoni, 2005). This has led to a significant increase in the demand for the grapes by commercial enterprises for production of dietary supplements, creating new opportunities for growers.

Even though the current and future market outlook has been promising with tremendous potential for growers to reap both economies of scale and scope, investment in muscadine grape production and marketing is yet to catch up. On average, from 2010 to 2014 used production of grapes (in U.S. dollars) in Georgia (the leading muscadine grape producing state) increased by $65 \%$ while production (in tons) during the same

\begin{tabular}{llll}
\hline $\begin{array}{l}\text { Units } \\
\text { To convert U.S. to SI, } \\
\text { multiply by }\end{array}$ & U.S. unit & SI unit & $\begin{array}{l}\text { To convert SI to U.S., } \\
\text { multiply by }\end{array}$ \\
\hline 0.4047 & $\mathrm{acre}(\mathrm{s})$ & $\mathrm{ha}$ & 2.4711 \\
45.3592 & $\mathrm{cwt}$ & $\mathrm{kg}$ & 0.0220 \\
0.3048 & $\mathrm{ft}$ & $\mathrm{m}$ & 3.2808 \\
3.7854 & gal & $\mathrm{L}$ & 0.2642 \\
0.7457 & horsepower & $\mathrm{kW}$ & 1.3410 \\
2.54 & inch(es) & $\mathrm{cm}$ & 0.3937 \\
0.4536 & $\mathrm{lb}$ & $\mathrm{kg}$ & 2.2046 \\
28.3495 & $\mathrm{oz}$ & $\mathrm{g}$ & 0.0353 \\
0.4732 & $\mathrm{pt}$ & $\mathrm{L}$ & 2.1134 \\
907.1847 & ton(s) & $\mathrm{kg}$ & 0.0011 \\
2241.7023 & ton(s)/acre & $\mathrm{kg} \cdot \mathrm{ha}^{-1}$ & 0.0004 \\
& & &
\end{tabular}


Table 1. Estimated fixed cost items used for producing muscadine grapes in Georgia in 2015.

\begin{tabular}{|c|c|c|c|c|c|c|c|}
\hline Item & Size/unit ${ }^{z}$ & Power $^{\mathrm{y}}$ & $\begin{array}{l}\text { Purchase } \\
\text { price }(\$)\end{array}$ & $\begin{array}{l}\text { Annual } \\
\text { use (h) }\end{array}$ & Life (yr) & $\begin{array}{l}\text { Performance } \\
\text { rate }(h / \text { acre })^{z}\end{array}$ & $\begin{array}{c}\text { Salvage } \\
\text { value (\$) }\end{array}$ \\
\hline Subsoiler (one shank) & shank & 2WD $75 \mathrm{hp}$ & 585.90 & 54 & 23 & 1.078 & 134.76 \\
\hline Chisel plow & $8 \mathrm{ft}$ & 2WD $75 \mathrm{hp}$ & $7,836.15$ & 150 & 12 & 0.22 & $1,802.31$ \\
\hline Disk harrow & $10 \mathrm{ft}$ & MFWD $50 \mathrm{hp}$ & $2,415.00$ & 180 & 10 & 0.33 & 555.45 \\
\hline Trailer utility & $10 \mathrm{ft}$ & $2 W D 50 \mathrm{hp}$ & $1,155.00$ & 200 & 15 & 0.6 & 265.65 \\
\hline Sprayer (broadcast and band) & $12 \mathrm{ft}$ & $4 \times 4$ & 626.85 & 200 & 5 & 0.6 & 144.18 \\
\hline Spray (broadcast) & $12 \mathrm{ft}$ & $2 W D 50 \mathrm{hp}$ & $5,250.00$ & 200 & 8 & 0.062 & $1,207.50$ \\
\hline Utility vehicle & $4 \times 4$ & & $13,125.00$ & 200 & 13 & 0.249 & $3,018.75$ \\
\hline Trailer fruit $(4 \times 6 \mathrm{ft})$ & trip & $4 \times 4$ & 525.00 & 200 & 15 & 1 & 120.75 \\
\hline Tractor & & MFWD 75 hp & 42,000 & 600 & 15 & 0.78 & $10,500.00$ \\
\hline
\end{tabular}

${ }^{\mathrm{z}} \mathrm{l} \mathrm{ft}=0.3048 \mathrm{~m}, \mathrm{l} \mathrm{h} /$ acre $=2.471 \mathrm{lh} \cdot \mathrm{ha}^{-1}$.

y lhorsepower $(\mathrm{hp})=0.7457 \mathrm{~kW}, 2 \mathrm{WD}=$ two-wheel drive, $\mathrm{MFWD}=$ mechanical front-wheel drive, $4 \times 4=$ four-wheel drive.

period only increased by $38 \%$ [U.S. Department of Agriculture (USDA), 2015]. In addition, total acreage planted in Georgia increased by only 6.6\% from 1500 acres in 2010 to 1600 acres in 2014 (USDA, 2015). This can partly be attributed to the relatively limited awareness and consumption of muscadine grapes nationally and internationally, high cost of entering the current niche market, competition from other crops, limited access to loans, and the absence of information to help farmers make better investment decisions in the face of production and marketing risk.

Farm enterprise budgets remain the primary approach used by extension professionals and growers to gauge the profitability of a farm venture as well as to secure farm loans. Where they exist, such budgets rarely reflect the diversity in technology and risks faced by growers. Most if not all of the existing budgets are based on traditional (nonstochastic) costs, yield, and price estimates, with little or no consideration for uncertainty stemming from production and marketing risk inherent in agriculture. Traditional sensitivity analysis or risk-rated approaches which involve calculating revenues under different scenarios (Byrd et al., 2006; Fonsah and Hudgins, 2007; Fonsah et al., 2007, 2008, 2012) are often based on selected values and subjective expectations of future prices, and fail to consider the dependency between yields and prices in a systematic approach. For niche markets such as muscadine grapes where market data are generally absent, and individual-level data tightly safeguarded, the data on which budgets and sensitivity analysis are conducted are likely to be even less reliable or representative. The results derived from this approach, especially with the adoption of new technology that often comes with high variability and risk, are more likely to give users a false sense of confidence about expected returns on the investment, resulting in higher rates of insolvency and disappointment when such profits are not realized in the real world.

The development and application of stochastic budget analysis largely has been ignored by applied economists. To the best of our knowledge, few applications of stochastic budget exist in the literature (Falk, 1994; Jason et al., 2007; Peacock et al., 1995; Rayburn, 2009; Werth et al., 1991) despite tremendous advances in computation over recent decades, and none of the studies account for the dependency between output and prices. In addition, all of the existing applications are in animal production with none in the fruit and vegetable industry. The study most related to ours is by Rayburn (2009). The author illustrated the use of statistical functions in Excel (Microsoft, Redmond, WA) to produce a stochastic no-till grasslegume hay budget from a deterministic template. However, this study 1) did not account for structural dependency between yields and prices, 2) employed a normal distribution that has been found not to fit yield distributions, and 3 ) made no attempt to evaluate and compare investment decisions under the traditional and stochastic approach. A relatively small number of traditional muscadine budgets currently exist in the literature. For instance, Noguera et al. (2005) developed budgets for producing muscadine grapes for wine and juice in Arkansas using a singlewire trellis system; Carpio et al. (2008) extended it to estimate and compare the cost of production and profitability of muscadine grapes in North Carolina under the single-wire and Geneva double-curtain trellis systems with and without irrigation. In both studies, only the traditional budgeting approach and sensitivity analysis was employed.

In this study, we develop and investigate a simple framework for stochastic farm enterprise budgets. Specifically, we estimate the costs, revenues, and profitability measures of producing muscadine grapes in Georgia using both the traditional nonstochastic approach in the first stage (Georgia is currently the largest producer of muscadine grapes in the United States with over 1600 planted acres). Next, we develop a probabilistic framework that accounts for yield and price dependency through price elasticity, and extend the traditional framework to a stochastic approach using Monte Carlo simulations. The later allows us to derive the likelihood of obtaining specific investment outcomes under different degrees of elasticity. Finally, we compare results derived from the traditional (nonstochastic) and stochastic approach.

\section{Materials, methods, and assumptions}

We estimated cost and returns based on growing 1 acre of 'Noble' muscadine grape for juice and fresh 
Table 2. Year 1 estimated variable costs per acre of producing muscadine grapes using single-curtain trellis system and irrigation in Georgia in 2015.

\begin{tabular}{|c|c|c|c|c|c|c|}
\hline Operation/input ${ }^{\mathrm{z}}$ & Unit $^{\mathrm{z}}$ & Quantity & $\begin{array}{l}\text { Equipment/power } \\
\text { costs }(\$ / \mathrm{acre})^{\mathrm{z}}\end{array}$ & $\begin{array}{l}\text { Material costs } \\
\quad(\$ / \text { acre })\end{array}$ & $\begin{array}{l}\text { Labor costs } \\
(\$ / \text { acre })\end{array}$ & $\begin{array}{c}\text { Total costs } \\
\text { (\$/acre })\end{array}$ \\
\hline \multicolumn{7}{|l|}{ Weed control } \\
\hline Sprayer (broadcast and band) & $12 \mathrm{ft}$ & 3 & 3.01 & & 18.45 & 21.46 \\
\hline $\mathrm{N}$-phosphomethyl & gal & 0.6 & & 25.17 & & 25.17 \\
\hline Fluazifop- $p$-butyl & pt & 0.75 & & 18.94 & & 18.94 \\
\hline Surfactant nonionic & $\mathrm{pt}$ & 0.75 & & 1.28 & & 1.28 \\
\hline Hand labor & $\mathrm{h}$ & 1 & & & 8.00 & 8.00 \\
\hline Soil test & each & 1 & & 6.62 & & 6.62 \\
\hline Lime & ton & 2 & & 83.90 & & 83.90 \\
\hline Hand labor & $\mathrm{h}$ & 0.6 & & & 4.80 & 4.80 \\
\hline Chisel plow & $8 \mathrm{ft}$ & 1 & 2.48 & & 2.26 & 4.74 \\
\hline Disk harrow & $6 \mathrm{ft}$ & 1 & 2.22 & & 3.38 & 5.61 \\
\hline Muscadine vine & each & 181 & & 904.69 & & 904.69 \\
\hline Plastic twine & each & 181 & & 19.67 & & 19.67 \\
\hline Hand labor & $\mathrm{h}$ & 4.5 & & & 36.00 & 36.00 \\
\hline \multicolumn{7}{|l|}{ Build trellis grape } \\
\hline End post wine grape & each & 24 & & 215.67 & & 215.67 \\
\hline Wood post $(3.5 \times 6.5 \mathrm{ft})$ & each & 181 & & 590.02 & & 590.02 \\
\hline Wire-wine grape & $\mathrm{ft}$ & 3,630 & & 307.66 & & 307.66 \\
\hline Grow tubes & each & 181 & & 145.54 & & 145.54 \\
\hline Wire links & each & 12 & & 28.03 & & 28.03 \\
\hline Wire vises & each & 24 & & 43.03 & & 43.03 \\
\hline Trailer utility & $10 \mathrm{ft}$ & & 3.51 & & 6.15 & 9.66 \\
\hline Hand labor & $\mathrm{h}$ & 100 & & & 800.00 & 800.00 \\
\hline Ammonium nitrate $(34 \mathrm{~N}-0 \mathrm{P}-0 \mathrm{~K})$ & cwt & 0.5 & & 15.46 & & 15.46 \\
\hline \multicolumn{7}{|l|}{ Irrigate } \\
\hline Hand labor & $\mathrm{h}$ & 10 & & & 80.00 & 80.00 \\
\hline Half of water needed & $100 \mathrm{gal}$ & 27 & & 8.35 & & 8.35 \\
\hline \multicolumn{7}{|l|}{ Mow between rows } \\
\hline Rotary cutter & $6 \mathrm{ft}$ & 6 & 23.84 & & 35.18 & 59.01 \\
\hline Side dresser (one row) & $3 \mathrm{ft}$ & 1 & 8.34 & & 8.67 & 17.01 \\
\hline Ammonium nitrate $(34 \mathrm{~N}-0 \mathrm{P}-0 \mathrm{~K})$ & cwt & 1 & & 30.91 & & 30.91 \\
\hline \multicolumn{7}{|l|}{ Train and stake } \\
\hline Hand labor & $\mathrm{h}$ & 68 & & & 544.00 & 544.00 \\
\hline Spray (broadcast 27 inches) & inch & 1 & 0.48 & & 0.64 & 1.12 \\
\hline Iprodione $41 \%$ & $\mathrm{pt}$ & 1.75 & & 34.45 & & 34.45 \\
\hline Total & & & 79.90 & $2,972.89$ & $2,007.93$ & $5,060.71$ \\
\hline
\end{tabular}

market using a single-wire trellis system with drip irrigation, planted $20 \mathrm{ft}$ apart in the row and $12 \mathrm{ft}$ between the rows giving about 181 vines/acre. While other cultivars such as Fry and Supreme are locally grown substitutes, Noble is recommended for juice and fresh market in Georgia. We consider recommended production practices by researchers and major growers of muscadine grapes in Georgia.

Machinery and equipment cost estimates were obtained based on theoretical and accounting methods recommended by the AAEA Task Force on Commodity Costs and Returns (AAEA, 2000). Table 1 presents machinery and equipment, and their corresponding specified use in the process. We assume 2015 prices for the machinery and equipment, 
Table 3. Year 2 estimated variable costs per acre of producing muscadine grapes using single-curtain trellis system and irrigation in Georgia in 2015.

\begin{tabular}{|c|c|c|c|c|c|c|}
\hline Operation/input ${ }^{\mathrm{z}}$ & Unit $^{\mathrm{z}}$ & Quantity & $\begin{array}{c}\text { Equipment/power } \\
\text { costs ( } \$ / \text { acre })\end{array}$ & $\begin{array}{l}\text { Material costs } \\
\quad(\$ / \text { acre })\end{array}$ & $\begin{array}{c}\text { Labor costs } \\
(\$ / \text { acre })\end{array}$ & $\begin{array}{l}\text { Total costs } \\
(\$ / \text { acre })\end{array}$ \\
\hline \multicolumn{7}{|l|}{ Pruning and training } \\
\hline Hand labor & $\mathrm{h}$ & 48 & & & 384.00 & 384.00 \\
\hline Rotary cutter & $6 \mathrm{ft}$ & 7 & 27.81 & & 41.04 & 68.85 \\
\hline \multicolumn{7}{|l|}{ Trellis repair } \\
\hline Sprayer (broadcast and band) & $12 \mathrm{ft}$ & 6 & 6.02 & & 36.90 & 42.92 \\
\hline Dichlobenil 4\% & $\mathrm{lb}$ & 5 & & 11.65 & & 11.65 \\
\hline Paraquat dichloride & $\mathrm{pt}$ & 10 & & 44.16 & & 44.16 \\
\hline \multicolumn{7}{|l|}{ Replant grapes } \\
\hline Hand labor & $\mathrm{h}$ & 2 & & & 16.00 & 16.00 \\
\hline Spray (broadcast 27 inches) & inch & 1 & 0.48 & & 0.48 & 0.96 \\
\hline Ammonium nitrate $(34 \mathrm{~N}-0 \mathrm{P}-0 \mathrm{~K})$ & cwt & 2 & & 61.82 & & 61.82 \\
\hline \multicolumn{7}{|l|}{ Irrigate } \\
\hline Hand labor & $\mathrm{h}$ & 12 & & & 96.00 & 96.00 \\
\hline Half of water needed & $100 \mathrm{gal}$ & 41.5 & & 12.83 & & 12.83 \\
\hline Side dresser (one row) & $3 \mathrm{ft}$ & 1 & 8.34 & & 8.67 & 17.01 \\
\hline Ammonium nitrate $(34 \mathrm{~N}-0 \mathrm{P}-0 \mathrm{~K})$ & cwt & 1 & & 30.91 & & 30.91 \\
\hline Sprayer (broadcast and band) & $12 \mathrm{ft}$ & 2 & 2.01 & & 12.30 & 14.31 \\
\hline Ethoxycarbonyl & $\mathrm{pt}$ & 3 & & 14.01 & & 14.01 \\
\hline Total & & & 48.55 & 301.34 & 632.50 & 982.38 \\
\hline
\end{tabular}

Table 4. Year 3 estimated variable costs per acre of producing muscadine grapes using single-curtain trellis system and irrigation in Georgia in 2015.

\begin{tabular}{|c|c|c|c|c|c|c|}
\hline Operation/input ${ }^{\mathrm{z}}$ & Unit $^{\mathrm{z}}$ & Quantity & $\begin{array}{l}\text { Equipment/power } \\
\text { costs }(\$ / \text { acre })^{z}\end{array}$ & $\begin{array}{c}\text { Material costs } \\
(\$ / \text { acre })\end{array}$ & $\begin{array}{l}\text { Labor costs } \\
(\$ / \text { acre })\end{array}$ & $\begin{array}{c}\text { Total costs } \\
(\$ / \text { acre })\end{array}$ \\
\hline \multicolumn{7}{|l|}{ Pruning and training } \\
\hline \multicolumn{7}{|l|}{ Mow between rows } \\
\hline Rotary cutter & $6 \mathrm{ft}$ & 7 & 27.81 & & 41.04 & 68.85 \\
\hline \multicolumn{7}{|l|}{ Trellis repair } \\
\hline Hand labor & $\mathrm{h}$ & 2 & & & 16.00 & 16.00 \\
\hline Ammonium nitrate $(34 \mathrm{~N}-0 \mathrm{P}-0 \mathrm{~K})$ & cwt & 3 & & 91.27 & & 91.27 \\
\hline \multicolumn{7}{|l|}{ Irrigate } \\
\hline Hand labor & $\mathrm{h}$ & 12 & & & 96.00 & 96.00 \\
\hline Half of water needed & $100 \mathrm{gal}$ & 55 & & 16.73 & & 16.73 \\
\hline Paraquat dichloride & $\mathrm{pt}$ & 12 & & 52.16 & & 52.16 \\
\hline Sprayer (broadcast and band) & $12 \mathrm{ft}$ & 3 & 3.01 & & 18.45 & 21.46 \\
\hline Phosmet & $\mathrm{lb}$ & 4 & & 40.33 & & 40.33 \\
\hline Fenpropathrin & $\mathrm{OZ}$ & 10 & & 14.67 & & 14.67 \\
\hline \multicolumn{7}{|l|}{ Harvest muscadine } \\
\hline Hand labor & $\mathrm{h}$ & 50 & & & 400.00 & 400.00 \\
\hline Muscadine (lug) & & 151 & & 697.32 & & 697.32 \\
\hline \multicolumn{7}{|l|}{ Fruit gathering } \\
\hline Trailer fruit $(4 \times 6 \mathrm{ft})$ & & 1 & 1.59 & & 10.25 & 11.84 \\
\hline Total & & & 50.65 & 958.12 & $1,128.42$ & $2,137.19$ \\
\hline
\end{tabular}

${ }^{\mathrm{z}} 1 \mathrm{ft}=0.3048 \mathrm{~m}, 4 \times 4=$ four-wheel drive, $\mathrm{l} \mathrm{cwt}=45.3592 \mathrm{~kg}, \mathrm{l} \mathrm{gal}=3.7854 \mathrm{~L}, \mathrm{l} \mathrm{pt}=0.4732 \mathrm{~L}, \mathrm{l} \mathrm{lb}=0.4535 \mathrm{~kg}, \mathrm{l} \mathrm{oz}=28.3495 \mathrm{~g}, \$ 1.00 / \mathrm{acre}=\$ 2.471 \mathrm{l} / \mathrm{ha}$. 
Table 5. Year 4 estimated variable costs per acre of producing muscadine grapes using single-curtain trellis system and irrigation in Georgia in 2015.

\begin{tabular}{|c|c|c|c|c|c|c|}
\hline Operation/input ${ }^{\mathrm{z}}$ & $\mathrm{Unit}^{\mathrm{z}}$ & Quantity & $\begin{array}{l}\text { Equipment/power } \\
\text { costs }(\$ / \text { acre })^{\mathrm{z}}\end{array}$ & $\begin{array}{c}\text { Material costs } \\
(\$ / \text { acre })\end{array}$ & $\begin{array}{c}\text { Labor costs } \\
(\$ / \text { acre })\end{array}$ & $\begin{array}{c}\text { Total costs } \\
\text { (\$/acre) }\end{array}$ \\
\hline \multicolumn{7}{|l|}{ Pruning and training } \\
\hline Hand labor & $\mathrm{h}$ & 60 & & & 480.00 & 480.00 \\
\hline Rotary cutter & $6 \mathrm{ft}$ & 7 & 27.81 & & 41.04 & 68.85 \\
\hline \multicolumn{7}{|l|}{ Trellis repair } \\
\hline Hand labor & $\mathrm{h}$ & 2 & & & 16.00 & 16.00 \\
\hline Ammonium nitrate $(34 \mathrm{~N}-0 \mathrm{P}-0 \mathrm{~K})$ & cwt & 3 & & 91.27 & & 91.27 \\
\hline \multicolumn{7}{|l|}{ Irrigate } \\
\hline Hand labor & $\mathrm{h}$ & 12 & & & 96.00 & 96.00 \\
\hline Half of water needed & $100 \mathrm{gal}$ & 61 & & 18.56 & & 18.56 \\
\hline \multicolumn{7}{|l|}{ Spot spray } \\
\hline \multicolumn{7}{|l|}{ Weed control } \\
\hline Sprayer (broadcast) & $12 \mathrm{ft}$ & 6 & 6.02 & & 36.90 & 42.92 \\
\hline Paraquat dichloride & $\mathrm{pt}$ & 12 & & 52.16 & & 52.16 \\
\hline Sprayer (broadcast) & $12 \mathrm{ft}$ & 2 & 2.01 & & 12.30 & 14.31 \\
\hline Phosmet & $\mathrm{lb}$ & 4 & & 40.33 & & 40.33 \\
\hline Fenpropathrin & $\mathrm{OZ}$ & 10 & & 14.67 & & 14.67 \\
\hline \multicolumn{7}{|l|}{ Harvest muscadine } \\
\hline Hand labor & $\mathrm{h}$ & 150 & & & $1,200.00$ & $1,200.00$ \\
\hline Muscadine (lug) & & 128 & & 591.10 & & 591.10 \\
\hline \multicolumn{7}{|l|}{ Fruit gathering } \\
\hline Trailer fruit $(4 \times 6 \mathrm{ft})$ & & 13 & 20.63 & & 133.25 & 153.88 \\
\hline
\end{tabular}

${ }^{\mathrm{z}} \mathrm{l} \mathrm{ft}=0.3048 \mathrm{~m}, 4 \times 4=$ four-wheel drive, $\mathrm{l} \mathrm{cwt}=45.3592 \mathrm{~kg}, \mathrm{l} \mathrm{gal}=3.7854 \mathrm{~L}, \mathrm{l} \mathrm{pt}=0.4732 \mathrm{~L}, 1 \mathrm{lb}=0.4535 \mathrm{~kg}, \mathrm{loz}=28.3495 \mathrm{~g}, \$ 1.00 / \mathrm{acre}=\$ 2.4711 / \mathrm{ha}$.

Table 6. Summary of years 1 to 4 estimated equipment, power, material, and labor costs per acre of producing muscadine grapes using single-curtain trellis system and irrigation in Georgia in 2015.

\begin{tabular}{lcccr}
\hline $\mathbf{Y r}^{\mathbf{z}}$ & $\begin{array}{c}\text { Equipment/power } \\
\text { costs }(\$ / \text { acre })^{\mathrm{z}}\end{array}$ & $\begin{array}{c}\text { Material costs } \\
(\$ / \text { acre })\end{array}$ & $\begin{array}{c}\text { Labor costs } \\
(\$ / \text { acre })\end{array}$ & $\begin{array}{c}\text { Total costs } \\
(\$ / \text { acre })\end{array}$ \\
\hline 1 & 79.90 & $2,972.89$ & $2,007.93$ & $5,060.71$ \\
2 & 48.55 & 301.34 & 632.50 & 982.38 \\
3 & 50.65 & 958.12 & $1,128.42$ & $2,137.19$ \\
4 & 70.70 & 899.33 & $2,057.57$ & $3,027.59$ \\
\hline${ }^{2} \mathrm{We}$ assume the total annual costs from years 5 to 20 is $\$ 3,027.59 /$ acre; $\$ 1.00 /$ acre $=\$ 2.4711 / \mathrm{ha}$.
\end{tabular}

a salvage value equal to $23 \%$ of price; taxes, insurance, and housing cost at $1 \%$ of price; and a $5 \%$ interest rate in calculating capital recovery factor. To estimate the cost of ownership and repairs and maintenance per acre we also assume a repair and maintenance cost for the life of the machinery and equipment as a percentage of price, ranging from $25 \%$ to $61 \%$, and a performance rate of each machinery item ranging from 1.08 to 0.22 . These assumptions are based on estimates published by Iowa State
University (2005), Mississippi State University (2010), and University of Illinois at Urbana-Champaign (2008). Note that performance rate accounts for machinery speed and time used in making turns at the end of rows. To estimate the cost of operating the machinery, we assume a skilled labor cost of \$10.25/ $\mathrm{h}$, whereas unskilled labor for other farming operations such as planting is valued at $\$ 8 / \mathrm{h}$. We deliberately leave out the cost of land as is generally done in enterprise budgeting, due to high variation of land value within the state. The materials for muscadine grape productions and unit prices were obtained from local dealers and growers in Georgia, as well as the literature adjusting for inflation.

For the nonstochastic (traditional) enterprise budget, we assumed yields of 8 tons/acre for matured vines (year 4 and beyond) and a market price of $\$ 500 /$ ton based on information provided by growers and 2012 production and price data from 18 counties in Georgia collected by University of Georgia Cooperative Extension. These values are coupled with annual cost estimates to calculate total annual revenues, net cash flow, and accumulated cash flows over the life of the project ( 20 years). From these, we derived break-even year (BEY) and net present value (NPV) for investing in muscadine grape production. Finally, we conducted traditional sensitivity analysis by repeating the analysis for a combination 
Table 7. Estimated cash flow of producing muscadine grapes using single-curtain trellis system and irrigation in Georgia in 2015.

\begin{tabular}{|c|c|c|c|c|c|}
\hline Yr & $\begin{array}{l}\text { Annual yield } \\
\text { (tons/acre) }^{\mathrm{z}}\end{array}$ & $\begin{array}{l}\text { Total costs } \\
(\$ / \text { acre })^{\mathrm{z}}\end{array}$ & $\begin{array}{l}\text { Total revenue } \\
(\$ / \text { acre })\end{array}$ & $\begin{array}{c}\text { Net cash flow } \\
(\$ / \text { acre })\end{array}$ & $\begin{array}{c}\text { Accumulated } \\
\text { cash flow (\$/acre) }\end{array}$ \\
\hline 0 & 0 & $4,280.20$ & 0.00 & $-4,280.20$ & $-4,280.20$ \\
\hline 1 & 0 & 780.51 & 0.00 & -780.51 & $-5,060.71$ \\
\hline 2 & 1 & 982.38 & 500.00 & -482.38 & $-5,543.09$ \\
\hline 3 & 2 & $2,137.19$ & 750.00 & $-1,387.19$ & $-6,930.28$ \\
\hline 4 & 8 & $3,027.59$ & $4,000.00$ & 972.41 & $-5,957.88$ \\
\hline 5 & 8 & $3,027.59$ & $4,000.00$ & 972.41 & $-4,985.47$ \\
\hline 6 & 8 & $3,027.59$ & $4,000.00$ & 972.41 & $-4,013.06$ \\
\hline 7 & 8 & $3,027.59$ & $4,000.00$ & 972.41 & $-3,040.65$ \\
\hline 8 & 8 & $3,027.59$ & $4,000.00$ & 972.41 & $-2,068.24$ \\
\hline 9 & 8 & $3,027.59$ & $4,000.00$ & 972.41 & $-1,095.83$ \\
\hline 10 & 8 & $3,027.59$ & $4,000.00$ & 972.41 & -123.43 \\
\hline 11 & 8 & $3,027.59$ & $4,000.00$ & 972.41 & 848.98 \\
\hline 12 & 8 & $3,027.59$ & $4,000.00$ & 972.41 & $1,821.39$ \\
\hline 13 & 8 & $3,027.59$ & $4,000.00$ & 972.41 & $2,793.80$ \\
\hline 14 & 8 & $3,027.59$ & $4,000.00$ & 972.41 & $3,766.21$ \\
\hline 15 & 8 & $3,027.59$ & $4,000.00$ & 972.41 & $4,738.62$ \\
\hline 16 & 8 & $3,027.59$ & $4,000.00$ & 972.41 & $5,711.03$ \\
\hline 17 & 8 & $3,027.59$ & $4,000.00$ & 972.41 & $6,683.43$ \\
\hline 18 & 8 & $3,027.59$ & $4,000.00$ & 972.41 & $7,655.84$ \\
\hline 19 & 8 & $3,027.59$ & $4,000.00$ & 972.41 & $8,628.25$ \\
\hline 20 & 8 & $3,027.59$ & $4,000.00$ & 972.41 & $9,600.66$ \\
\hline Total & & $59,649.34$ & $69,250.00$ & $9,600.66$ & \\
\hline
\end{tabular}

${ }^{\mathrm{z}} 1 \mathrm{ton} / \mathrm{acre}=2241.7023 \mathrm{~kg} \cdot \mathrm{ha}^{-1}, \$ 1.00 /$ acre $=\$ 2.4711 / \mathrm{ha}$.

Table 8. Sensitivity analysis of break-even year (BEY) of producing muscadine grapes using single-curtain trellis system and irrigation in Georgia in 2015. The entries in the table represent the number of years required for the investment to breakeven; i.e., cost of production equals revenue generated.

\begin{tabular}{lcccccc}
\hline & \multicolumn{7}{c}{ Yield (tons/acre) } \\
\cline { 2 - 7 } Price $(\$)$ & 7 & 7.5 & $\mathbf{8}$ & $\mathbf{8 . 5}$ & $\mathbf{9}$ & $\mathbf{9 . 5}$ \\
\hline 350 & $>20$ & $>20$ & $>20$ & $>20$ & $>20$ & $>20$ \\
400 & $>20$ & $>20$ & $>20$ & $>20$ & 16.00 & 13.00 \\
450 & $>20$ & $>20$ & 16.00 & 12.00 & 10.00 & 9.00 \\
500 & 18.00 & 13.00 & 11.00 & 9.00 & 8.00 & 8.00 \\
550 & 12.00 & 10.00 & 8.00 & 8.00 & 7.00 & 7.00 \\
600 & 9.00 & 8.00 & 7.00 & 7.00 & 6.00 & 6.00 \\
\hline
\end{tabular}

${ }^{\mathrm{z}} 1 \mathrm{ton} /$ acre $=2241.7023 \mathrm{~kg} \cdot \mathrm{ha}^{-1}$.

Table 9. Sensitivity analysis of net present value (NPV) for producing muscadine grapes using single-curtain trellis system and irrigation in Georgia in 2015.

\begin{tabular}{lrrrrrr}
\hline & \multicolumn{7}{c}{ Yield (tons/acre) } \\
Price (\$) & \multicolumn{1}{c}{7} & \multicolumn{1}{c}{$\mathbf{7 . 5}$} & $\mathbf{8}$ & \multicolumn{1}{c}{$\mathbf{8 . 5}$} & \multicolumn{1}{c}{$\mathbf{9}$} & \multicolumn{1}{c}{$\mathbf{9 . 5}$} \\
\hline 350 & $-12,614.95$ & $-10,910.63$ & $-9,206.31$ & $-7,501.99$ & $-5,797.67$ & $-4,093.35$ \\
400 & $-9,096.17$ & $-7,148.38$ & $-5,200.59$ & $-3,252.79$ & $-1,305.00$ & 642.79 \\
450 & $-5,577.39$ & $-3,386.13$ & $-1,194.86$ & 996.40 & $3,187.67$ & $5,378.94$ \\
500 & $-2,058.62$ & 376.12 & $2,810.86$ & $5,245.60$ & $7,680.34$ & $10,115.08$ \\
550 & $1,460.16$ & $4,138.37$ & $6,816.59$ & $9,494.80$ & $12,173.02$ & $14,851.23$ \\
600 & $4,978.93$ & $7,900.62$ & $10,822.31$ & $13,744.00$ & $16,665.69$ & $19,587.38$ \\
\hline
\end{tabular}

${ }^{\mathrm{z}} 1 \mathrm{ton} / \mathrm{acre}=2471.0538 \mathrm{~kg} \cdot \mathrm{ha}^{-1}$.

of yields and prices ranging from 7 to 10 tons/acre and $\$ 350$ to $\$ 600$ per ton, respectively.

Next, we extended the traditional enterprise budget estimates to a stochastic framework to better account for uncertainty and structural dependence between yields and prices. To accomplish this, we assumed yields from years 4 to 20 are independently generated from a $\log$ normal $(\mathrm{LN})$ distribution with location parameter $(\mu) 1.93$ and scale parameter $(\sigma) 0.20$ while yields for years 2 and 3 are generated from a similar distribution with location 1.06 and scale 0.32 . That is:

$$
y_{i}=L N(\mu, \sigma),
$$

where $\mu=\frac{\log \left(v^{2}\right)}{\sqrt{v^{2}+\vartheta}}$ and $\sigma=\sqrt{\log \left(\frac{\vartheta}{v^{2}}+1\right)}$ with $v$ and $\vartheta$ as mean and variance, respectively. For $i=2,3$, we take $v=3$ and $\vartheta=1$ while for $i=4, \ldots$, 21 , we take $v=7$ and $\vartheta=2$. Just and Weninger (1999) and Ramirez (1997) showed that crop yields are not normally distributed. We used the LN distribution to capture the skewness of muscadine yields. The parameters (mean and SD) of the distribution were chosen to allow the full distribution of feasible yields to be simulated. The price elasticity of demand $(\eta)$ which shows the degree of responsiveness of quantity demanded to changes in price was estimated using 2012 price and yield data from 18 counties in Georgia using ordinary least squares specified as

$$
\log \left(y_{j}\right)=\eta_{0}+\eta \log \left(p_{j}\right)+\varepsilon_{j},
$$

where $y_{j}$ and $p_{j}$ are the yield and price in county $j$, respectively, and $\varepsilon_{j}$ is the error term. Note that with sufficient time series of muscadine yields and prices, improved estimates of elasticity can be obtained using an almost ideal demand system (AIDS). The price elasticity estimate $(\eta)$ was derived as -0.46 , implying that a $1 \%$ increase in the price of muscadine grapes will lead to $0.46 \%$ decrease in quantity demanded. This indicates that demand for muscadine grapes in Georgia is inelastic, thus current prices can be increased with little effect on the quantity demanded. We also considered upper and lower bound of $\eta$ in our simulations, taken as 0 and -1 , respectively. When $\eta=0$, it implies that demand is perfectly inelastic, a change in price will have no effect on the quantity demanded, that is, a $1 \%$ increase in price will lead to $0 \%$ change in quantity demanded. Similarly, when $\eta=-1$, it implies a $1 \%$ increase in price will lead to a $1 \%$ decrease in quantity demanded. Demand in this case $(\eta=-1)$ is set to be (unit) elastic. 


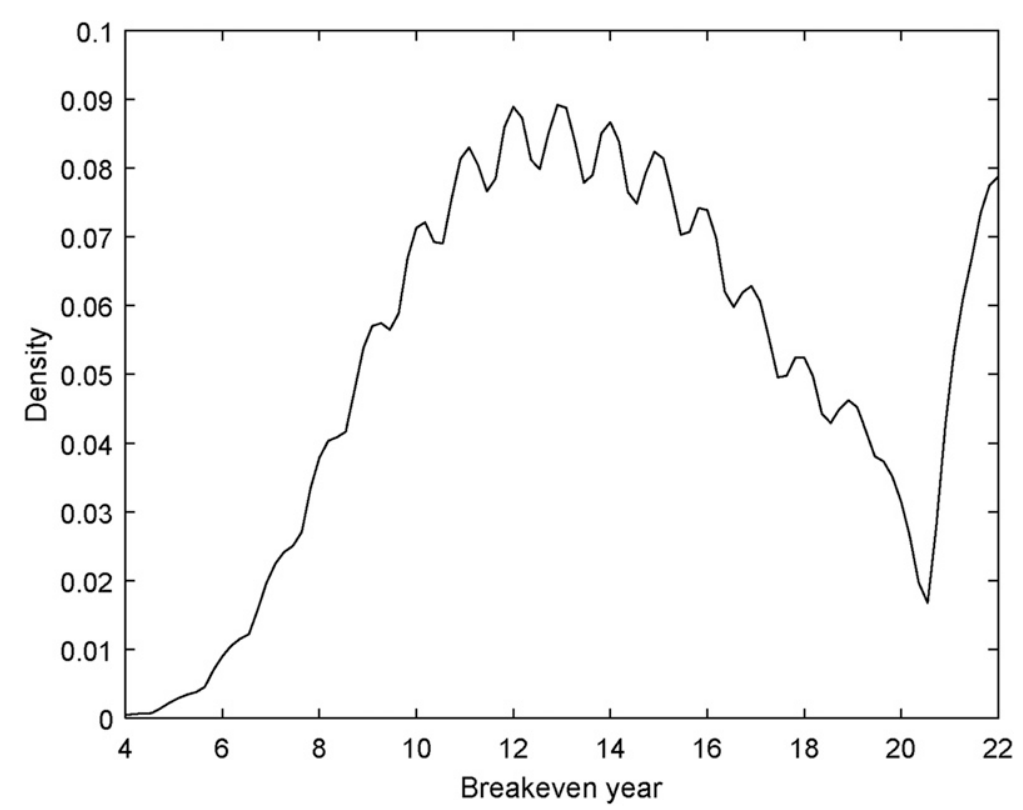

Fig. 1. Density of break-even year $($ BEY) (when elasticity $=0$ ) from producing muscadine grapes using single-curtain trellis system and irrigation in Georgia in 2015. BEY is the nth year during which the cost of producing muscadine grapes equals the revenue generated.



Fig. 2. Density of break-even year (BEY) (when elasticity $=-0.46$ ) from producing muscadine grapes using single-curtain trellis system and irrigation in Georgia in 2015. BEY is the nth year during which the cost of producing muscadine grapes equals the revenue generated.

To estimate the new price at which a sample yield drawn from the distribution is marketed, we used

$$
p^{n}=\left(\eta^{*} p^{0}+p^{0^{*}} \nabla y\right) / \nabla y
$$

where $\nabla y=\frac{y^{0}}{y^{n}-y^{0}}$ and $y^{0}$ and $p^{0}$ are the starting yield and prices taken as 7 tons/acre and $\$ 500 /$ ton, respectively. each, estimate the new market price using the sample and initial values; 3 ) calculate annual revenues, net cash flows, accumulated cash flows, BEY and NPV and save estimates; and 4) repeat step 1 to 310,000 times to obtain the distribution of each estimate including profitability measures. The probability of obtaining a BEY of $n$ is derived as the proportion of the simulations with a BEY of $n$, whereas the probability of break even at $n$ years or less is the proportion of the simulations with $n$ or less BEY. Similarly, the probability of obtaining an NPV of $x$ is derived as the proportion of the simulations with NPV of $x$, whereas the probability of obtaining an NPV of at least $x$ or more is the proportion of the simulations with $x$ or more value of NPV.

\section{Results and discussions}

Traditional ENTERPRISE BUDGET. Tables 2 to 5 present estimated costs for muscadine production in years $1,2,3$, and 4 , respectively, whereas Table 6 summarizes the estimated costs for each of the first 4 years by equipment and power, material, and labor. As expected, the total cost is highest in year 1 due to the initial cost of establishment, which includes trellis building and irrigation set up. The cost of setting up drip irrigation on 1 acre in Georgia was estimated at $\$ 884$.67. Material costs account for more than half $(59 \%)$ of the cost in year 1 , followed by labor cost (37\%), whereas equipment and power is the least $(2 \%)$ cost. In years 2 and 3, labor cost accounts for $64 \%$ and $53 \%$, whereas $31 \%$ and $45 \%$ were material cost respectively. Equipment and power accounts for $5 \%$ and $2 \%$, respectively, in the same time periods. During the year 4 , considered to be full production, the total annual cost is $\$ 3027.59 /$ acre; with most $(68 \%)$ of the cost associated with labor, followed be materials $(30 \%)$ and then equipment and power $(2 \%)$. The year 4 is the first year of full production following maturity. We assume that the total annual cost of production from years 4 to 20 , the length of production life, is constant and equals \$3027.59/acre.

Table 7 presents cash flows throughout the project life assuming yields of 1 and 2 tons/acre for years 2 and 3 , respectively; 8 tons/acre and 


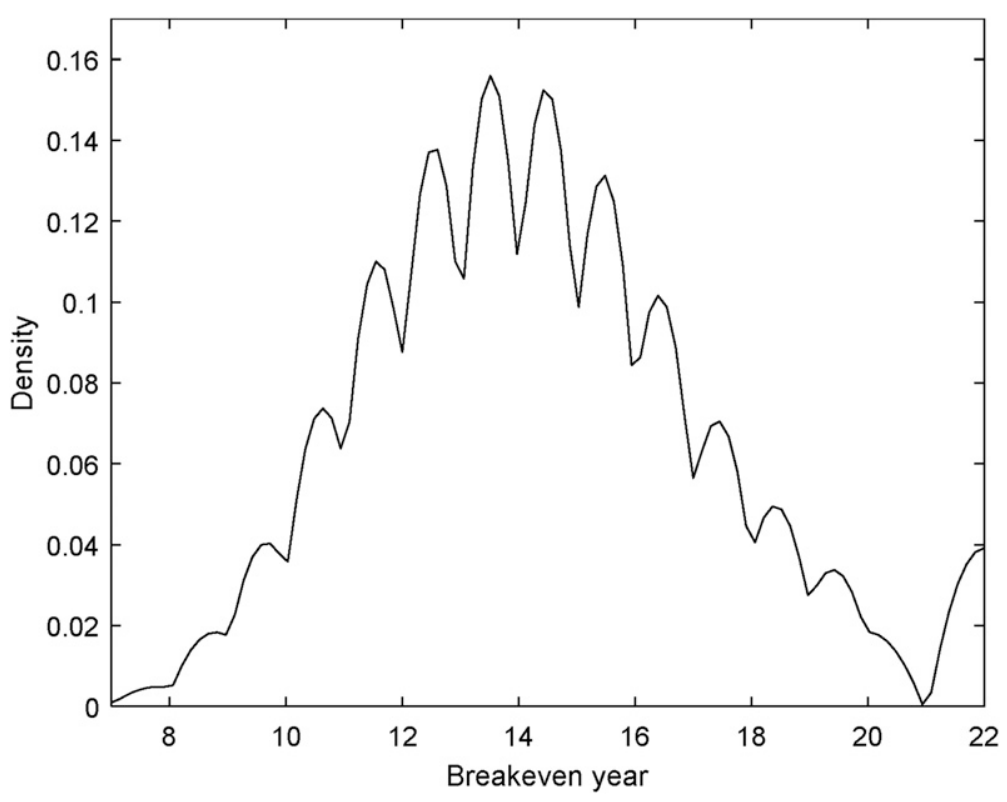

Fig. 3. Density of break-even year (BEY) (when elasticity $=-1$ ) from producing muscadine grapes using single-curtain trellis system and irrigation in Georgia in 2015. BEY is the nth year during which the cost of producing muscadine grapes equals the revenue generated.

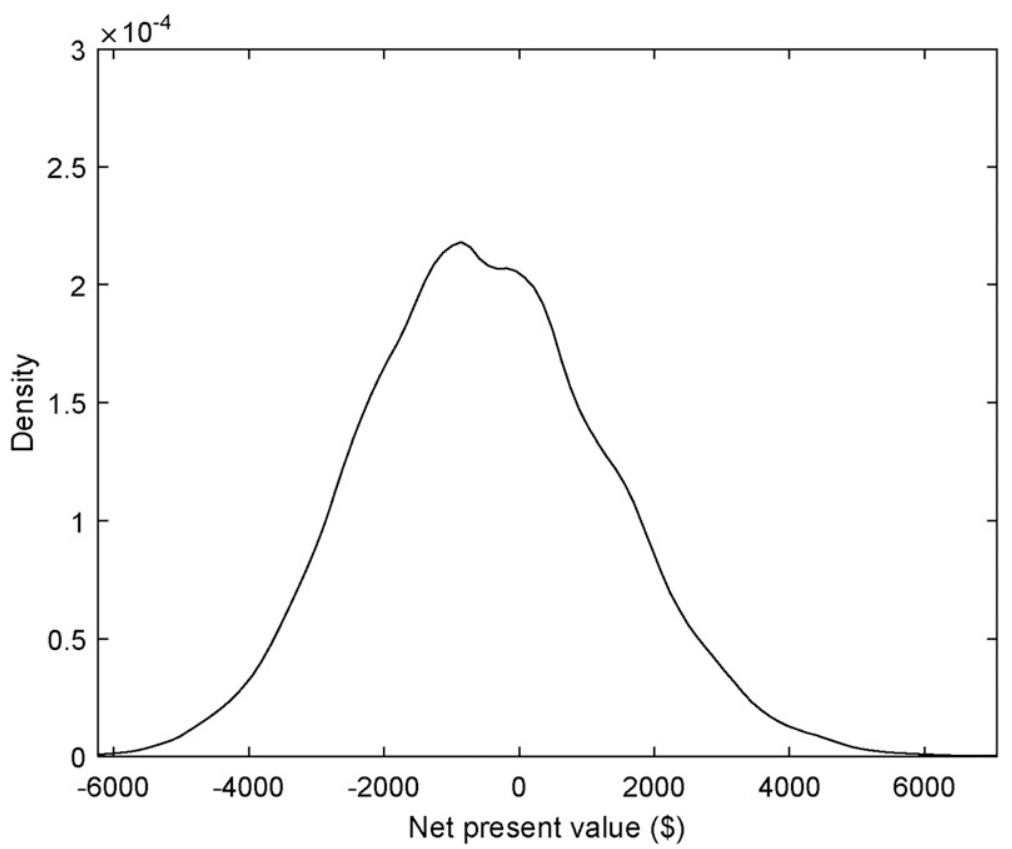

Fig. 4. Density of net present value (NPV) (when elasticity $=0$ ) from producing muscadine grapes using single-curtain trellis system and irrigation in Georgia in 2015. NPV is the difference between the present value of cash inflows and the present value of cash outflows from producing muscadine for 20 years.

a constant wholesale market price of $\$ 500 /$ ton from years 4 to 20 . Based on these, grape production will begin to produce a positive accumulated cash flow during the year 11 also called the BEY. The NPV of this investment is \$2810.86 indicating a profitable venture under these scenarios. Tables 8 and 9 present results for sensitivity analysis of the investment under different yield and price combinations. The results show that the investment gets a positive NPV and break even for a combination of prices and yields of at least $\$ 500 /$ ton and 7.5 tons/acre, respectively. Expectedly, the investment is more profitable and attractive for higher combinations of prices and yields. However, for yields of 7 tons/ acre or less and wholesale prices of $\$ 500 /$ ton or less, muscadine grape production gets a negative NPV and hardly break even during the projects life, indicating an increasingly bad investment. In addition, for a price of $\$ 450$ and $\$ 400$ per ton, yields of 7.5 tons/acre or less and 8.5 tons/acre or less, respectively, will not break even, and for a $\$ 350 /$ ton market price, none of the yields will break even making these scenarios not attractive to pursue.

STOCHASTIC ENTERPRISE BUDGET. Figures 1 to 3 present the distributions of BEY estimates when price elasticity is $0,-0.46$, and -1 , respectively, whereas Figs. 4 to 6 present the distributions of NPV estimates given price elasticity of $0,-0.46$, and -1 , respectively. Summary of BEY and NPV distributions under the three scenarios of elasticity are reported in Tables 10 and 11 , respectively.

Results show that with $95 \%$ confidence, BEY range is 7 to 22 years when price elasticity is 0 , and 9 to 22 years when price elasticity -0.46 and -1 . In all three scenarios, the median BEY is 14. Note that a BEY of 22 indicates the presence of investment scenarios that do not break even during the life of the project. This point is reiterated in Fig. 1 , which illustrate the tapering off of the right tail of the BEY distribution beyond the year 20 . The area under the distribution beyond the year 20 represents the probability of the investment not achieving break even during the project's life. On the other hand, 95\% of the time when price elasticity is 0 , -0.46 , and -1 , the range of NPV is -3914 to $3198,-2552$ to 1583 , and -2266 to 1057 , respectively; each with a negative median NPV.

More specifically, Tables 12 and 13 report estimated probabilities of obtaining specific BEY and NPV, respectively, under the three scenarios of price elasticities. Results in Table 12 show that under all three scenarios of price elasticity, there is a high $(0.80$ to 0.93 ) probability of obtaining a BEY during the project life (less than 20 years). Observing increasingly lower BEYs becomes much more likely. For example, the probabilities of realizing BEYs of less than 16 , less than 12 , less than 10 , and less 


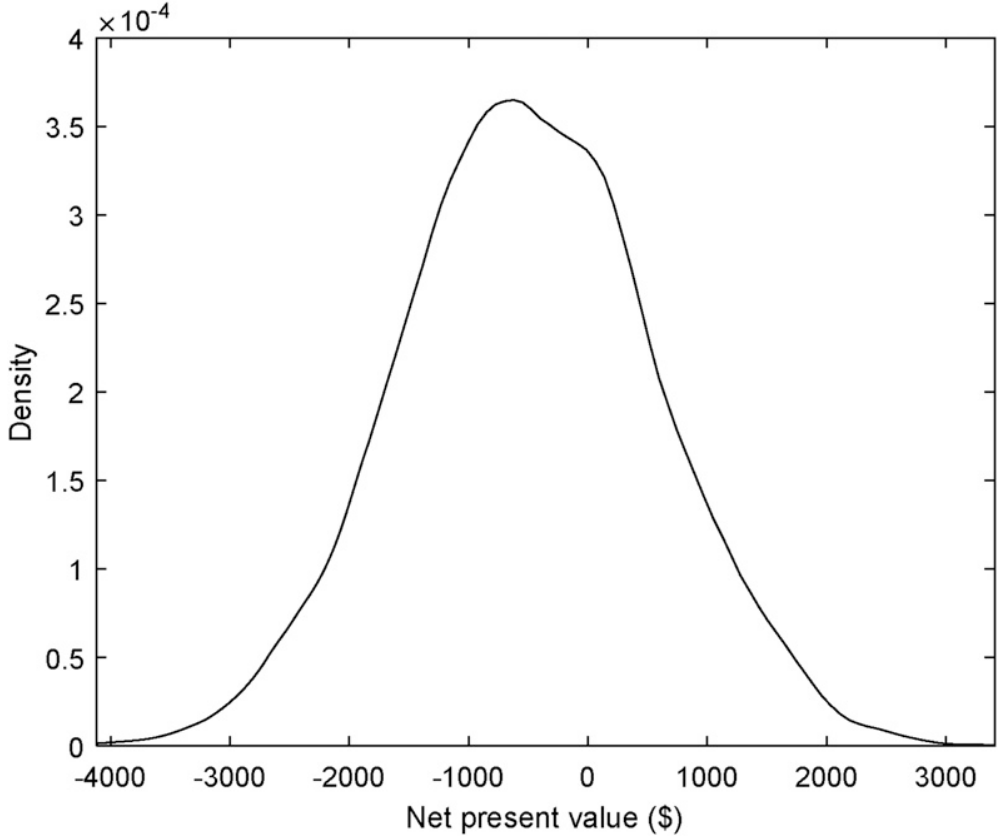

Fig. 5. Density of net present value (NPV) (when elasticity $=-0.46$ ) from producing muscadine grapes using single-curtain trellis system and irrigation in Georgia in 2015. NPV is the difference between the present value of cash inflows and the present value of cash outflows from producing muscadine for 20 years.

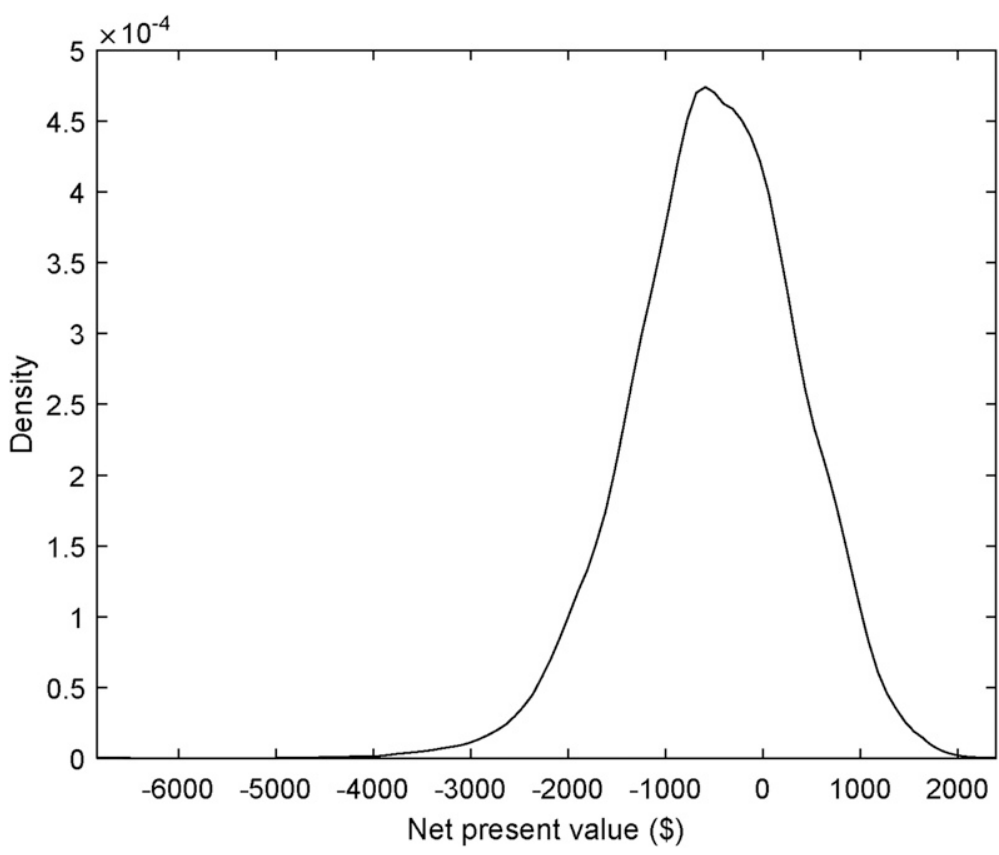

Fig. 6. Density of net present value (NPV) (when elasticity $=-1$ ) from producing muscadine grapes using single-curtain trellis system and irrigation in Georgia in 2015. NPV is the difference between the present value of cash inflows and the present value of cash outflows from producing muscadine for 20 years.

than 8 years under all three elasticities considered are in the range of 0.586 to $0.671,0.157$ to $256,0.028$ to 0.114 , and 0.003 to 0.114 , respectively. Notice that our simulations also predict two trends pertaining to the tails of the distribution: 1) the likelihood of observing high BEY increases with increase in price elasticity of demand, whereas 2) the likelihood of observing low BEY tend to decrease with increase in price elasticity of demand. However, results in Table 13 show even lower probabilities (in the range of 0.28 to 0.38 ) of obtaining a positive NPV, meaning that a positive NPV of muscadine grape production is expected only $38 \%$ of the time. Similarly, and as expected, the likelihood of obtaining higher NPV amounts drastically declines with increase in the amount, and also decreases with increase in elasticity. For example, the probability of obtaining an NPV greater than $\$ 376(\$ 2800)$ ranges from 0.14 to $0.31(0.00$ to 0.04$)$.

TRA D I T I ONAL VERS US STOCHASTIC ENTERPRISE BUDGET. Comparing results from stochastic budget analysis (reported with uncertainty) with those from the traditional budget (reported with certainty) shows that estimates and investment decisions derived from the traditional budget are highly uncertain and overly optimistic since they could be far less likely to be realized in real world. For example, the traditional (nonstochastic) budget reveals (Tables 8 and 9) that 1 acre of muscadine grapes with yields of 7.5 tons/acre ( 8 tons/acre) at full production marketed at a wholesale price of $\$ 500 /$ ton will generate a NPV of \$376 (\$2800) and will break even during year 13 (year 11) with certainty; i.e., a probability of 1 . Although the stochastic budget [elasticity $=0($ Table 13$)]$ shows that the same investment will generate a NPV of $\$ 376$ (\$2800) or more only up to $31 \%(4 \%)$ of the time while the chances that the investment breaks even on year 12 or less is at most $26 \%$. In this scenario where demand is assumed to be perfectly inelastic (price elasticity $=0$ ), the confidence placed on traditional budget estimates and investment outcomes is overestimated at least 3 -fold.

\section{Conclusion}

Muscadine grapes occupy a niche market, sold as fresh fruits and also processed for jams, juice, and wine. High levels of resveratrol and other antioxidants found in the grapes that help protect against cardiovascular diseases, fight cancer-causing agents, and enhance the production of estrogen, a female sex hormone has led to significant increase in the demand of the grapes for production of dietary supplements. In addition, current demand is price inelastic, making price 
and profit surge, and a shift in the market equilibrium is inevitable.

While advances in biotechnology have ushered in over 100 improved muscadine grape cultivars, including disease-resistant, high-yielding, seedless, self-fertile, and high-juice-quality cultivars, investment in this sector is lagging partly due to lack of information to help guide current and new growers make better investment decisions. Traditional enterprise budgets mostly based on nonstochastic approaches suggest no uncertainty about the estimates and investment decisions and fail to account for the structural dependency between yields and prices. This study develops cost

Table 10. Summary of simulated break-even year (BEY) distribution of producing muscadine grapes using single-curtain trellis system and irrigation in Georgia in 2015.

\begin{tabular}{lccc}
\hline & \multicolumn{3}{c}{ Percentile (\%) } \\
\cline { 2 - 4 } Elasticity $^{\mathbf{z}}$ & $\mathbf{2 . 5}$ & $\mathbf{5 0}$ & $\mathbf{9 7 . 5}$ \\
\hline 0 & 7 & 14 & 22 \\
-0.46 & 9 & 14 & 22 \\
\hline
\end{tabular}

${ }^{\mathrm{z}}$ Price elasticity of demand; the degree to responsiveness of quantity demanded due to changes in price.

Table 11. Summary of simulated net present value (NPV) distribution of producing muscadine grapes using single-curtain trellis system and irrigation in Georgia in 2015.

\begin{tabular}{llcc}
\hline & \multicolumn{3}{c}{ Percentile (\%) } \\
\cline { 2 - 4 } Elasticity $^{\mathrm{z}}$ & $\mathbf{2 . 5}$ & $\mathbf{5 0}$ & $\mathbf{9 7 . 5}$ \\
\hline 0 & $-3,914.03$ & -533.409 & $3,198.132$ \\
-0.46 & $-2,552.4$ & -492.591 & $1,582.392$ \\
\hline
\end{tabular}

${ }^{\mathrm{z}}$ Price elasticity of demand; the degree to responsiveness of quantity demanded due to changes in price.

Table 12. Estimated break-even year (BEY) probabilities of producing muscadine grapes using single-curtain trellis system and irrigation in Georgia in 2015.

\begin{tabular}{lccccc}
\hline Elasticity $^{\mathrm{z}}$ & $\begin{array}{c}\boldsymbol{P}(\mathrm{BEY} \\
<\mathbf{2 0} \text { years })\end{array}$ & $\begin{array}{c}\boldsymbol{P}(\mathrm{BEY} \\
<\mathbf{1 6} \text { years })\end{array}$ & $\begin{array}{c}\boldsymbol{P}(\mathrm{BEY} \\
<\mathbf{1 2} \text { years })\end{array}$ & $\begin{array}{c}\boldsymbol{P}(\mathrm{BEY} \\
<\mathbf{1 0} \text { years })\end{array}$ & $\begin{array}{c}\boldsymbol{P}(\mathrm{BEY} \\
<\mathbf{8} \text { years })\end{array}$ \\
\hline 0 & 0.8089 & 0.5859 & 0.2561 & 0.1142 & 0.1142 \\
-0.46 & 0.9054 & 0.6247 & 0.1664 & 0.0397 & 0.0042 \\
-1 & 0.9274 & 0.6705 & 0.1567 & 0.0284 & 0.0019 \\
\hline
\end{tabular}

${ }^{\mathrm{z}}$ Price elasticity of demand; the degree to responsiveness of quantity demanded due to changes in price.

Table 13. Estimated net present value (NPV) probabilities of producing muscadine grapes using single-curtain trellis system and irrigation in Georgia in 2015.

\begin{tabular}{lccc}
\hline Elasticity $^{\mathrm{z}}$ & $\boldsymbol{P}(\mathrm{NPV}>\mathbf{\$ 0})$ & $P(\mathrm{NPV}>\mathbf{\$ 3 7 6})$ & $P(\mathrm{NPV}>\mathbf{\$ 2 8 0 0})$ \\
\hline 0 & 0.3781 & 0.3064 & 0.0369 \\
-0.46 & 0.3148 & 0.2013 & 0.0011 \\
-1 & 0.2803 & 0.1481 & 0.0000 \\
\hline
\end{tabular}

${ }^{\mathrm{z}}$ Price elasticity of demand; the degree to responsiveness of quantity demanded due to changes in price. confidence placed on traditional budget estimates and investment outcomes is overestimated at least 3 -fold. We expect estimates and investment decisions from the traditional and stochastic approach to converge in the case where sufficiently large historical data are used in deriving both budgets.

Based on our results, we strongly encourage the use of stochastic budget analysis or at least the reporting of uncertainty around cost, profitability, and investment decision estimates, especially for new agricultural practices or those with high volatility in revenues. Even though budgets are expected to serve as merely guides for growers, reporting objective levels of uncertainty will better expose growers to all possible production and marketing outcomes and the chances of realizing each. This will enable growers to make more informed decisions and to carefully choose an investment option that matches their level of risk aversion. Thus, a more risk averse grower will opt out of an investment with high and uncertain expected profits while a less risk averse grower will go for the riskier investment.

In the case where market time series data for yields and prices are available, estimating yield distributions, a copula structure for yields and prices, and price elasticity using AIDS before conducting simulations will render the results more reliable. Finally, applying this approach to other crops, and simulation (e.g., yield distribution) assumptions would make for good future research.

\section{Literature cited}

American Agricultural Economics Association. 2000. Commodity cost and returns handbook. A report of the AAEA task force on commodity costs and returns (February). Amer. Agr. Econ. Assn., Ames, IA.

Byrd, M.M., C.L. Escalante, E.G. Fonsah, and M.E. Wetzstein. 2006. Financial efficiency of methyl bromide alternatives for Georgia bell pepper industries. J. Amer. Soc. Farm Managers Rural Appraisers 69:31-39.

Carpio, C.E., C.D. Safley, and E.B. Poling. 2008. Estimated costs and investment analysis of producing and harvesting muscadine grapes in the southeastern United States. HortTechnology 18:308-317.

Conner, P.J. 2013. Instrumental textural analysis of muscadine grape germplasm. HortScience 48:1130-1134. 
Ector, B.J., J.B. Magee, C.P. Hegwood, and M.J. Coign. 1996. Resveratrol concentration in muscadine berries, juice, pomace, purees, seeds and wines. Amer. J. Enol. Viticult. 47:57-62.

Falk, C. 1994. Stochastic simulation of a small-scale meat packing plant. J. Food Distrib. Res. 25:39-46.

Fonsah, E.G., C.M. Ferrer, C. Escalante, and S. Culpepper. 2012. The use of budget analysis in assisting vegetable growers in the adoption of methyl bromide alternatives for weeds, diseases, and nematodes control for bell pepper in Georgia and the southeast. Univ. Georgia Coop. Ext. Serv. Bul. 1411:1-12.

Fonsah, E.G. and J. Hudgins. 2007. Financial and economic analysis of producing commercial tomatoes in the Southeast. J. Amer. Soc. Farm Managers Rural Appraisers 70:141-148.

Fonsah, E.G., G. Krewer, K. Harrison, and M. Bruorton. 2007. Risk rated economic returns analysis for southern highbush blueberries in soil in Georgia. HortTechnology 17:571-579.

Fonsah, E.G., G. Krewer, K. Harrison, and D. Stanaland. 2008. Economic returns using risk rated budget analysis for rabbiteye blueberries in Georgia. HortTechnology 18:506-515.

Gray, D.J., Z.T. Li, and S.A. Dhekney. 2014. Precision breeding of grapevine (Vitis vinifera) for improved traits. Plant Sci. 228:3-10.
Gray, D.J., Z.T. Li, T.N.L. Grant, D.A. Dean, R.N. Trigiano, and S.A. Dhekney. 2015. The application of precision breeding (PB) for crop improvement is fully consistent with the plant life cycle: The utility of PB for grapevine. Acta Hort. (In press).

Gu, J., C.Q. Wang, H.H. Fan, H.Y. Ding, X.L. Xie, and Y.M. Xu. 2006. Effects of resveratrol on endothelial progenitor cells and their contributions to reendothelialization in intima-injured rats. J. Cardiovasc. Pharmacol. 47:711-721.

Iowa State University. 2005. Estimating farm machinery cost. Machinery management. Iowa State Univ. Ext. Outreach, Agr. Decision Maker PM 710 (A3-29).

Jason, R.E., M. Sperow, G.E. D'Souza, and E.B. Rayburn. 2007. Stochastic simulation of pasture-raised beef production systems and implications for the Appalachian cow-calf sector. J. Sustain. Agr. 30 (4):27-51.

Just, E.R. and Q. Weninger. 1999. Are crop yields normally distributed? Amer. J. Agr. Econ. 81:287-304.

Mississippi State University. 2010. Muscadine-2010 Fruit and nut planning budgets. Mississippi State Univ., Dept. Agr. Econ., Budget Rpt. 2010-04.

Noguera, E., J. Morris, K. Striegler, and M. Thomsen. 2005. Production budgets for Arkansas wine and juice grapes. Arkansas Agr. Expt. Sta. Res. Rpt. 976.

Olas, B. and B. Wachowicz. 2005. Resveratrol, a phenolic antioxidant with effects on blood platelet functions. Platelets 16:251260.

Peacock, K., R. Nayga, R. Brumfield, J. Bacon, and D. Thatch. 1995. The economic feasibility of a New Jersey fresh tomato packing facility: A stochastic simulation approach. J. Food Distrib. Res. 26:2-9.

Ramirez, O.A. 1997. Estimation and use of a multivariate parametric model for simulating heteroskedastic, correlated, non-normal random variables: The case of corn belt corn, soybean, and wheat yields. Amer. J. Agr. Econ. 79:191-205.

Rayburn, E.B. 2009. Estimating economic risk using Monte Carlo enterprise budgets. Forage Grazinglands Jan. 2009. doi: 10.1094/FG-2009-0415-01-MG.

Signorelli, P. and R. Ghidoni. 2005. Resveratrol as an anticancer nutrient: Molecular basis, open questions and promises. J. Nutr. Biochem. 16:449-466.

University of Illinois at Urbana-Champaign. 2008. Machinery cost estimates: Farm business management. Dept. Agr. Consumer Econ., Univ. Illinois UrbanaChampaign.

U.S. Department of Agriculture (USDA). 2015. Quick Stats. 3 Nov. $2015<$ http:// www.nass.usda.gov/Quick_Stats/>.

Werth, L., J. Kinder, M. Nielsen, and S. Azzam. 1991. Use of a simulation model to evaluate the influence of reproductive performance and management decisions on net income in beef production. J. Anim. Sci. 69:4710-4721. 